\title{
Nasal Base Narrowing of the Caucasian Nose Through the Cerclage Technique
}

\section{Estreitamento da Base Nasal no Nariz Caucasiano através da Técnica de Cerclagem}

\author{
Marcos Mocellin*, Rogerio Pasinato**, Cezar Augusto Sarraff Berger***, \\ Caio Márcio Correia Soares $* * * *$, Arthur Grinfeld $* * * *$, Marina Serrato Coelho Fagundes $* * * * *$.
}

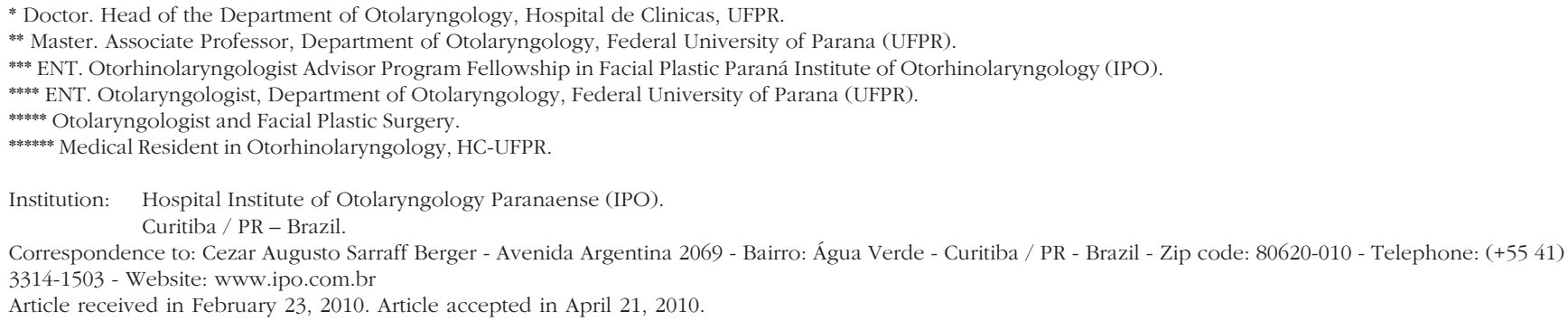

\section{SUMMARY}

Introduction:

Several techniques can be performed to reduce the nasal base (narrowing), as skin resection vestibular columellar skin resection, resection of skin in elliptical lip narinary, sloughing of skin and advancements (VY technique of Bernstein) and the use of cerclage sutures in the nasal base.

Objective: To evaluate the technique of cerclage performed in the nasal base, through endonasal rhinoplasty without delivery of basic technique, in the Caucasian nose, reducing the distance inter-alar flare and correcting the wing with consequent improvement in nasal harmony in the whole face.

Methods: A retrospective analysis by analysis of clinical documents and photos of 43 patients in whom cerclage was made of the nasal base by resecting skin ellipse in the region of the vestibule and the nasal base (modified technique of Weir) using colorless mononylon ${ }^{\circledR} 4$ " 0 " with a straight cutting needle. The study was conducted in 2008 and 2009 at Hospital of Paraná Institute of Otolaryngology - IPO in Curitiba, Parana - Brazil. Patients had a follow up ranging 7-12 months.

Results: In 100\% of cases was achieved an improvement in nasal harmony, by decreasing the inter-alar distance.

Conclusion: The encircling with minimal resection of vestibular skin and the nasal base is an effective method for

Keywords: the narrowing of the nasal base in the Caucasian nose, with predictable results and easy to perform. rhinoplasty, suture techniques, vestibuloplasty.

\section{RESUMO}

Introdução:

Diversas técnicas podem ser realizadas para diminuir a base nasal (estreitamento), como ressecção de pele vestibular, ressecção de pele columelar, ressecção de pele em elipse do bordo narinário, descolamentos e avançamentos de pele (técnica V-Y de Berstein) e o uso de suturas na cerclagem da base nasal.

Objetivo: Avaliar a técnica de cerclagem realizada na base nasal, através de rinosseptoplastia endonasal por técnica básica sem delivery, no nariz caucasiano, diminuindo a distância inter-alar e corrigindo o alar flare com consequente melhora da harmonia nasal no conjunto facial.

Método: Realizado estudo retrospectivo através da análise das fotos e documentos clínicos de 43 pacientes, nos quais foi confeccionada a cerclagem da base nasal, através da ressecção de pele em elipse da região do vestíbulo e base nasal (técnica de Weir modificada), utilizando-se fio mononylon ${ }^{\circledR}$ incolor 4"0" com agulha reta cortante. O estudo foi realizado nos anos de 2008 e 2009 no Hospital Instituto Paranaense de Otorrinolaringologia - IPO em Curitiba-Paraná, Brasil. Os pacientes tiveram um follow up que variou de 7 a 12 meses.

Resultados: $\quad$ Em 100\% dos casos foi atingida uma melhora na harmonia nasal, através da diminuição da distância inter-alar.

Conclusão: A cerclagem associada a ressecção mínima de pele vestibular e da base nasal é um método eficaz para o estreitamento da base nasal no nariz caucasiano, com resultados previsíveis e de fácil realização.

Palavras-chave: rinoplastia, técnicas de sutura, vestibuloplastia. 


\section{INTRODUCTION}

When performing a rhinoplasty various aesthetic parameters should be considered in addition to the features of the back and the definition of the nasal tip, a key point is the management of the nasal base (1-6) that includes the region of infratip (lobe), the luminous triangle Converse (facets), the lower lateral cartilages, narinários holes, the distance inter-alar, alar flare and the columella (Figure 1). Several papers mention different techniques to narrow the nasal base in the mestizo nose and african descent, (1-8) to mention but a few Caucasian nose. The enlargement of the nasal base after the surgery reductional the Caucasian nose and the permanence of the inter-alar distance greater than the inter-canthal distance (Figure 2), can be harmonized with the resection of the ellipse of skin and lip narinário posterior technique suture cerclage (3).

The aim of this study and describe the surgical narrowing of the nasal base, using the technique of Weir (10) modified the technique of cerclage suture for reduction of inter-alar distance and consequent better harmony of the whole Caucasian nose, facial aesthetic . Assess the results of the technique through the satisfaction of the surgeon and patient and through the incidence of postoperative complications.

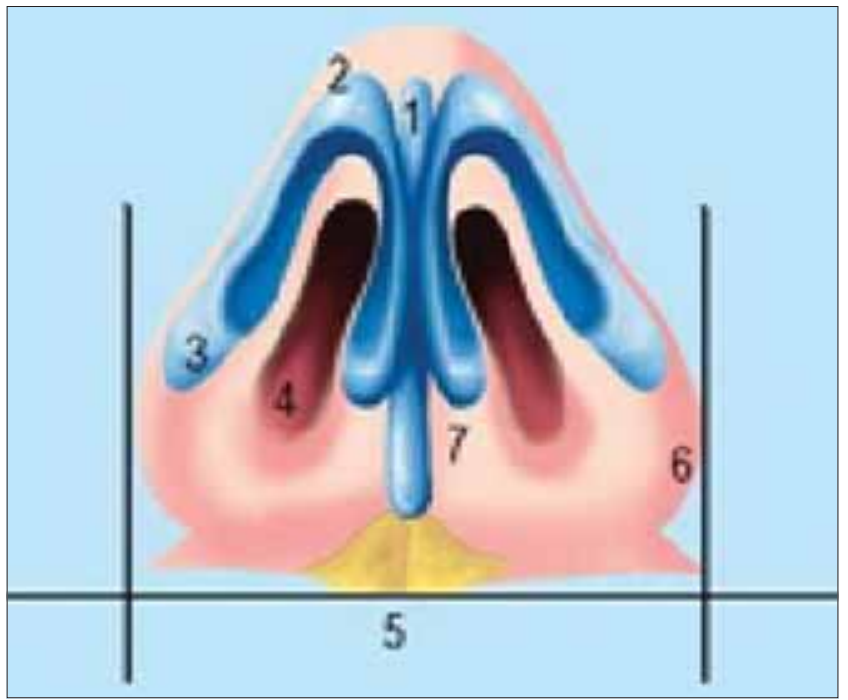

Figure 1. Aesthetic basis points (5.6).

1 - Infratip (lobe)

2 - Triangle light Converse (facets)

3 - lower lateral cartilages

4 - Openings narinários

5 - Distance inter-alar

6 - Alar flare

7 - Columella

\section{METHOD}

We evaluated the photos and charts of 43 patients with Caucasian nose, $42 \%(\mathrm{~N}=18)$ male and $58 \%(\mathrm{~N}=25)$ female, aged 16-52 years, mean 34 years, underwent rhinoplasty in need of narrowing of the nasal base, consecutively, from January 2008 to August 2009, the Hospital Paranaense of Otolaryngology - IPO, in Curitiba, Paraná - Brazil.

All patients underwent rhinoplasty classic Converse-Diamond $(11,12)$ under sedation and local anesthesia (xylocaine with epinephrine 1:100,000).

This technique is divided into six steps:

1. Intercartilaginous bilateral incision and detachment of the soft tissue structure with osteocartilaginous transfixation septocolumelar.

2. Separation of the upper lateral cartilage junction of the nasal septum, septoplasty with or without surgery of the turbinates and reduction of septal cartilage and upper lateral.

3. Surgery of the nasal tip with maneuver of La Garde and possible resection of the cephalic edge of the lower lateral cartilage (CLI) when necessary (McIndoe procedure).

4. Reduction hump bone chips using cutting-type Maury Parkes.

5. Osteotomies side by pecking, performed with an osteotome Converse $3 \mathrm{~mm}$ in $\mathrm{mm}$ in women and 4 men. Fracture and digital compression.

6. Septocolumelar suture the incision and intercartilaginous.

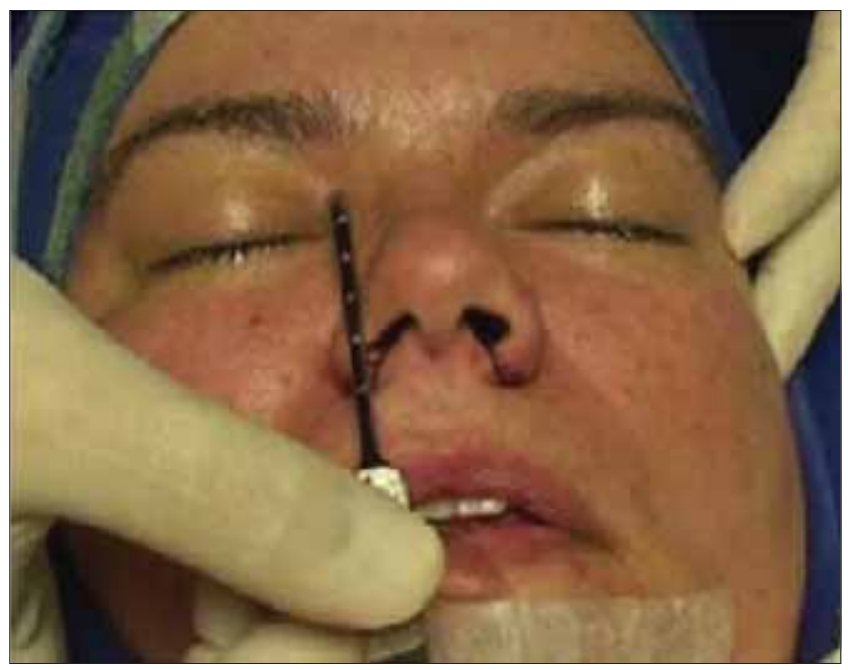

Figure 2. Inter-alar distance (9). Value of inter-canthal distance with the distance inter-alar. 
The narrowing of the distance inter-alar resection is performed through the skin and subcutaneous tissue of the vestibular floor and base of the nostril (Figure 3) previously marked with the use of compass Kaliper (Figure 4) and infiltration with a solution of xylocaine and adrenaline $1: 100,000$.

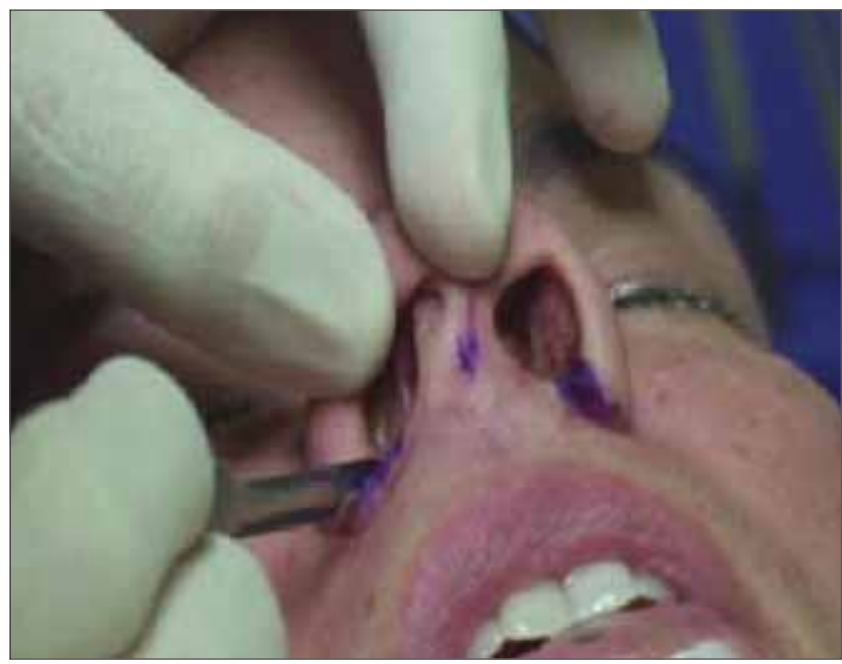

Figure 3. Technical Weir changed.

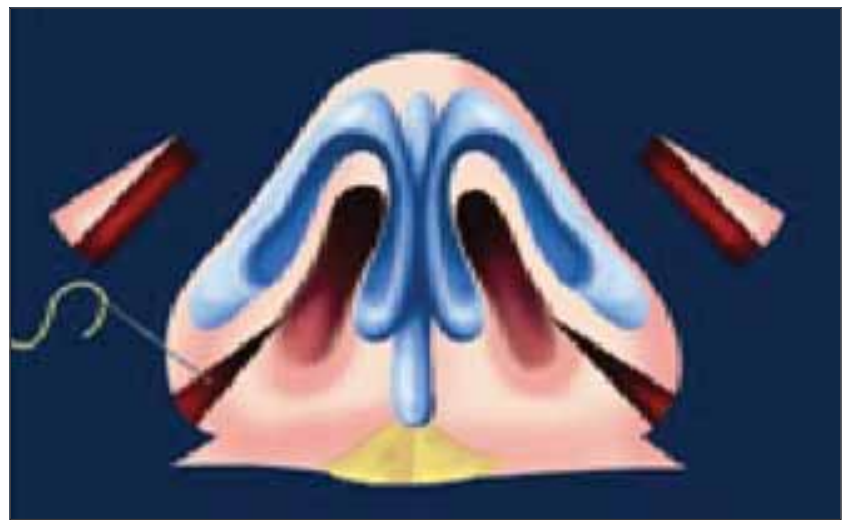

Figure 5. Resection of the skin of the vestibule and narinário ridge above the nasolabial groove.

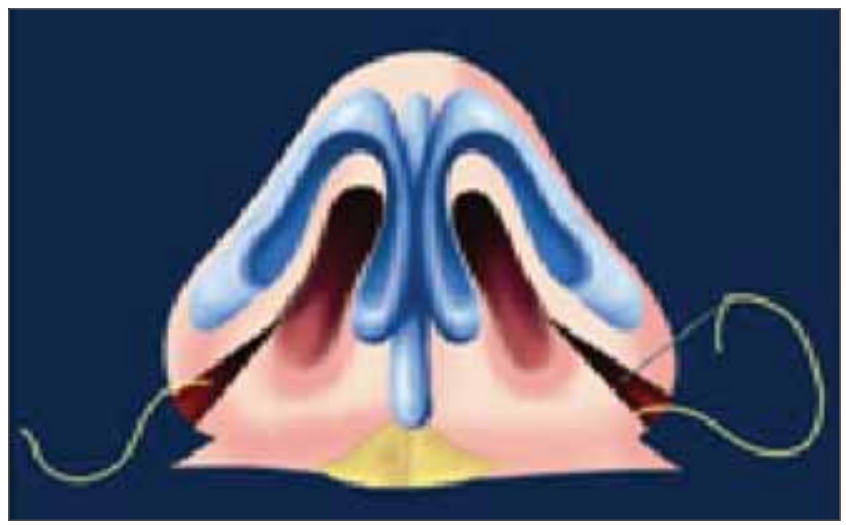

The suture in Cerclage should be performed as the last procedure.

Surgical technique (Schematic illustration):

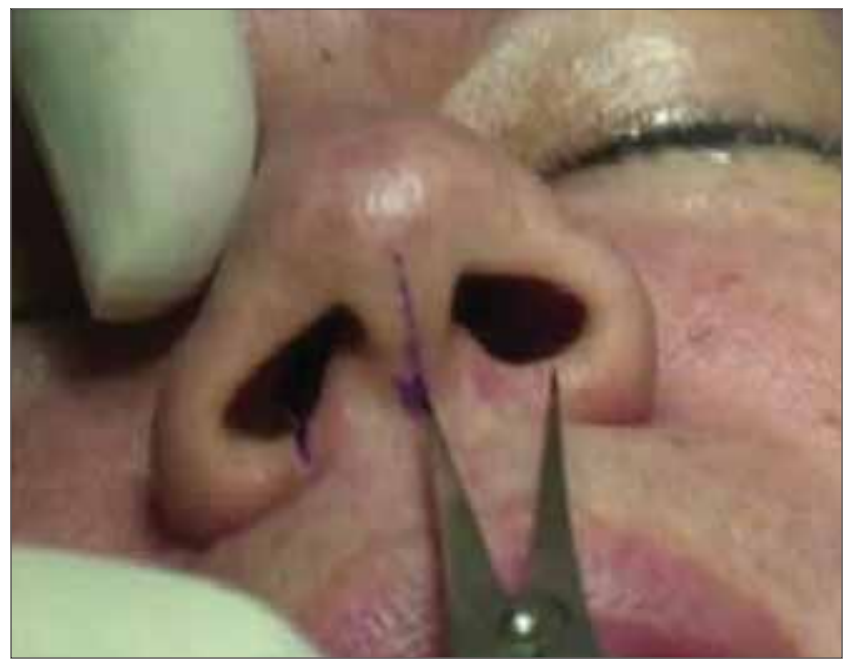

Figure 4. Dial with compass.

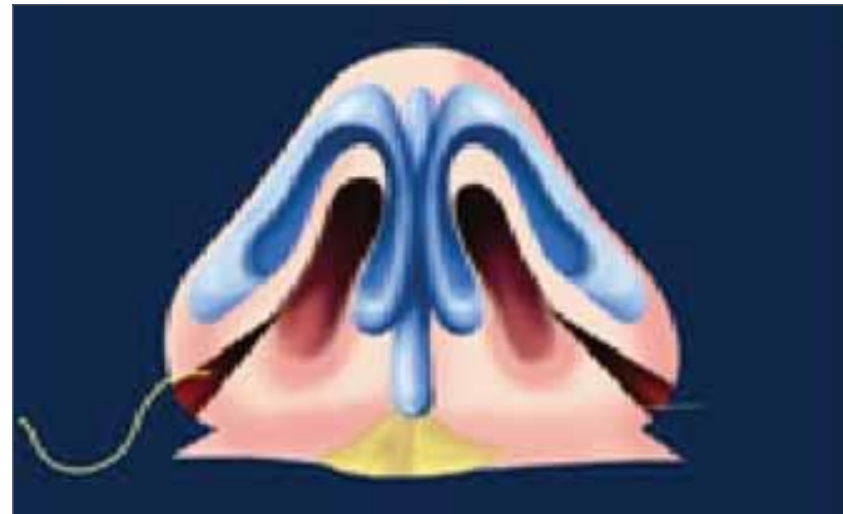

Figure 6. With needle straight and colorless mononylon ${ }^{\circledR} 4-0$, the procedure is the introduction of the needle on the rim side to the contralateral medial edge.

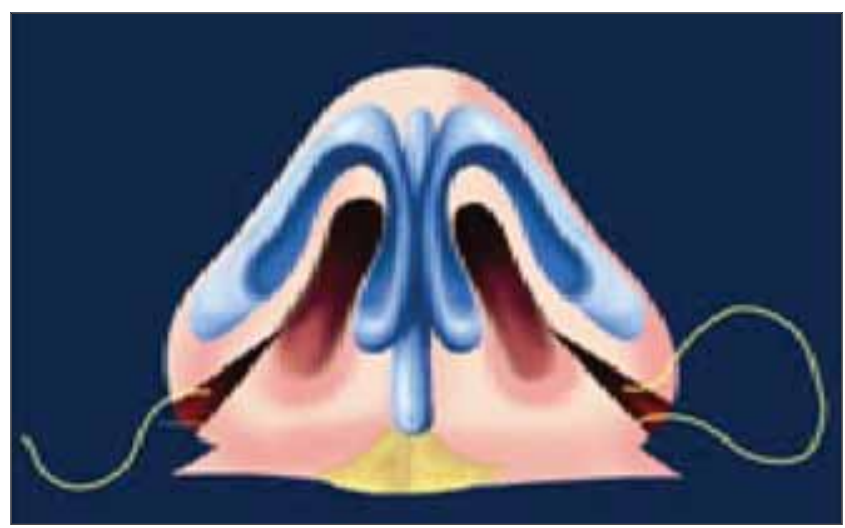

Figures 7 and 8. Returns in reverse, ie the lateral edge to the medial edge. 


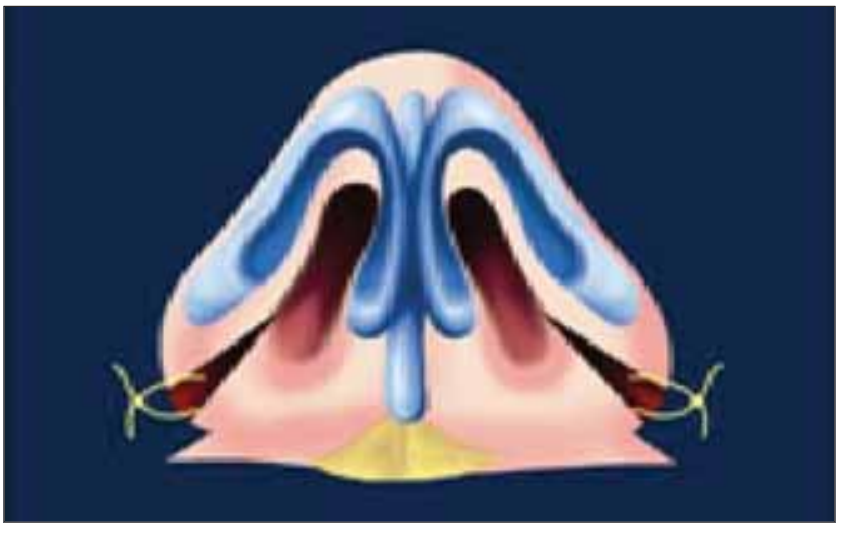

Figure 9. The suture is performed in both senses, ie from right to left and left to right.

\section{Steps to construct the Cerclage Technique:}

1. At surgery, mark the area of the vestibule and the edge narinário to be resected with methylene blue or gentian violet, measuring symmetrically with the aid of compass Kaliper (Figure 11).

2. Proceed to infiltration with $5 \mathrm{ml}$ syringe needle containing insulin xylocaine and 1:100,000 epinephrine (Figure 12).

3. Perform bevel incision in the area pre-selected (Figure 13).

4. Run through the mononylon ${ }^{\circledR} 4.0$ colorless, laterally to the medial contralateral nostril, the raw area resected (Figure 14).

5. Run through the wire to the nose through the contralateral incision.

6. Return the needle to the nose which started in the point, realizing the tightness of the suture gradually.

\section{RESULTS}

The suture cerclage was performed in 43 patients via the endonasal rhinoplasty without delivery of basic technique and correction of the nasal base with the technique of modified Weir.The surgeries were performed from January 2008 to August 2009. In 100\% of the cases reached a narrowing of the nasal base with satisfactory results for the patient and surgeon. There was no case of complication (stenosis, retraction, a sign of "Q", infection, hypertrophic scar) (13).

This study was approved by the institutional ethics committee (protocol number 005/2009).

Case I - female patient, 23 years, skin intermediate, pre-and postoperative 9 months (Figures 15 and 16).

Case III - female patient, 17 years, thin skin, pre-and post-operatively (Figures 17 and 18).

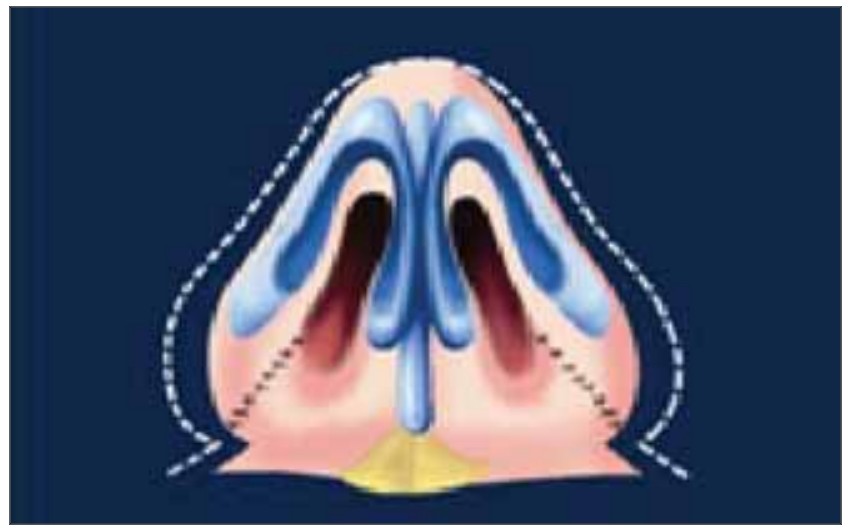

Figure 10. Finally, close to the skin with mononylon ${ }^{\circledR}$ 5.0. Note: The sequence is repeated in the contralateral nostril, as described by Gruber (3), 2009.

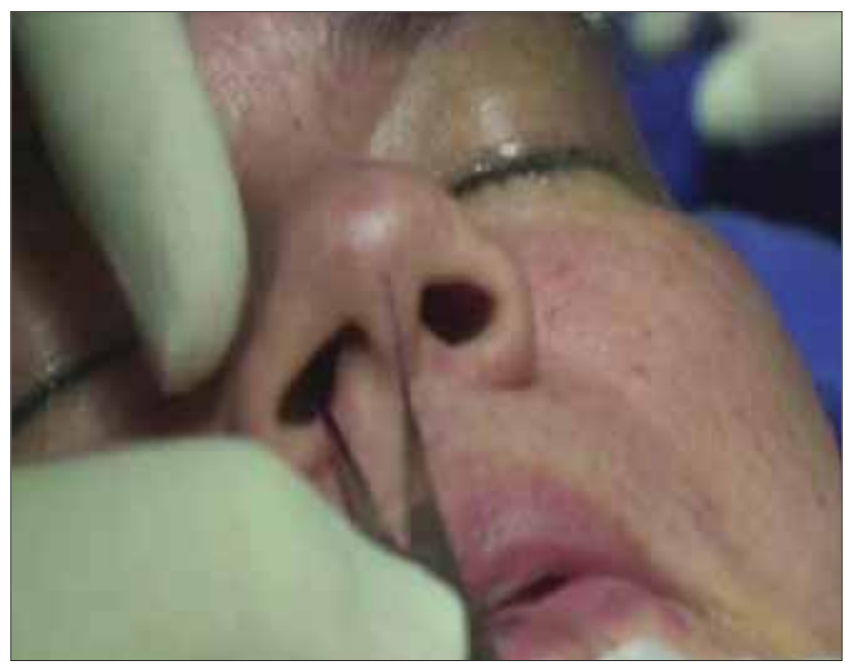

Figure 11. Step 1.

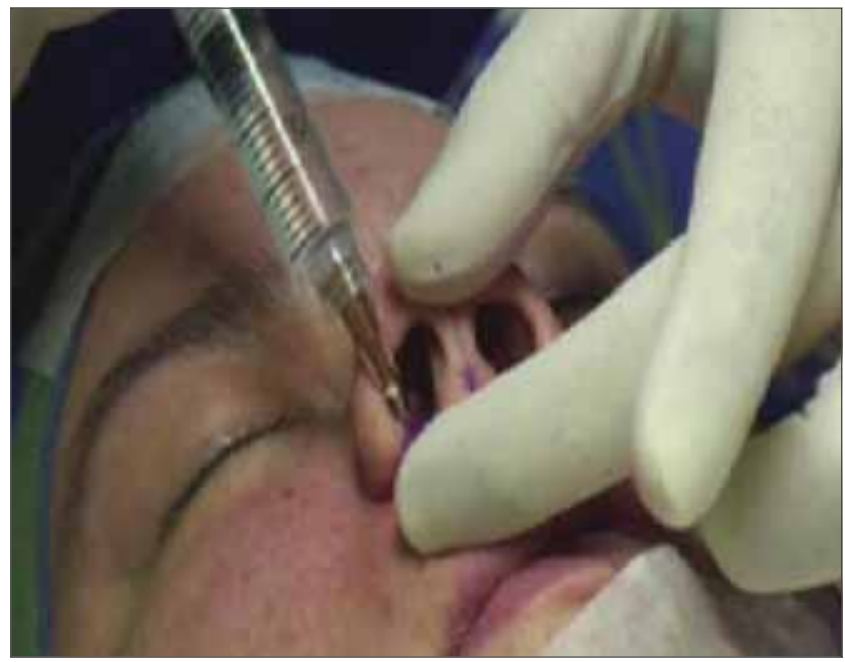

Figure 12. Step 2. 


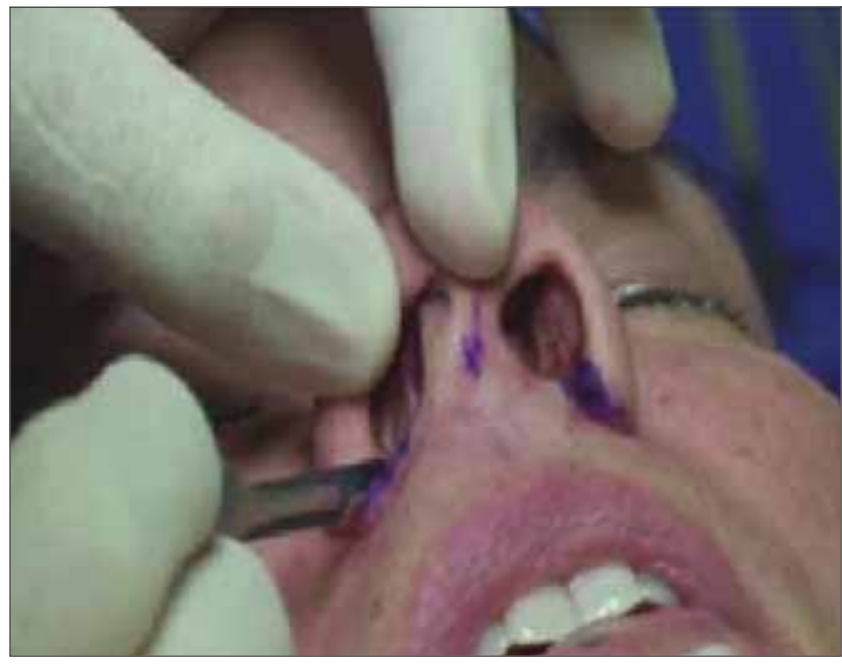

Figure 13. Step 3.

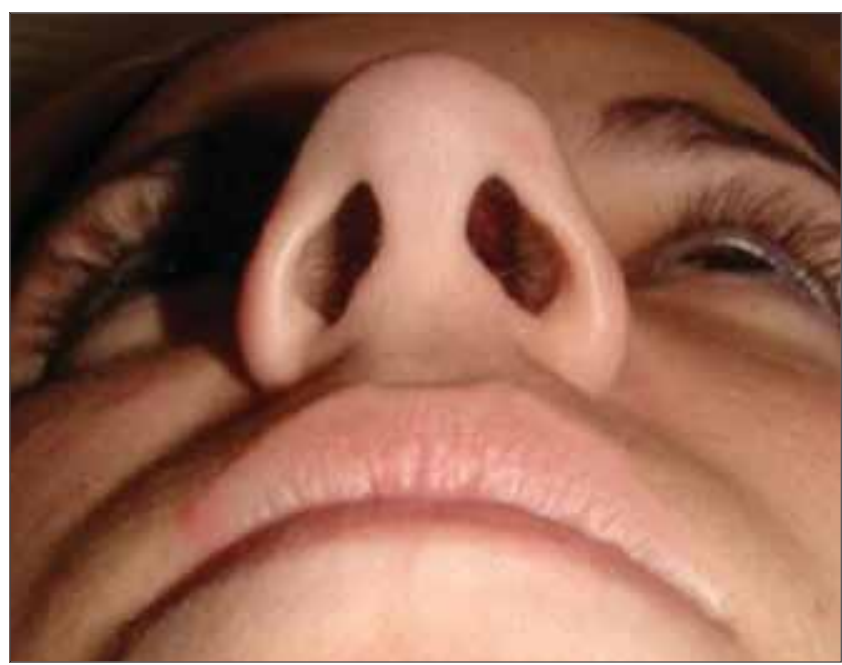

Figure 15. Pre operative view basis.

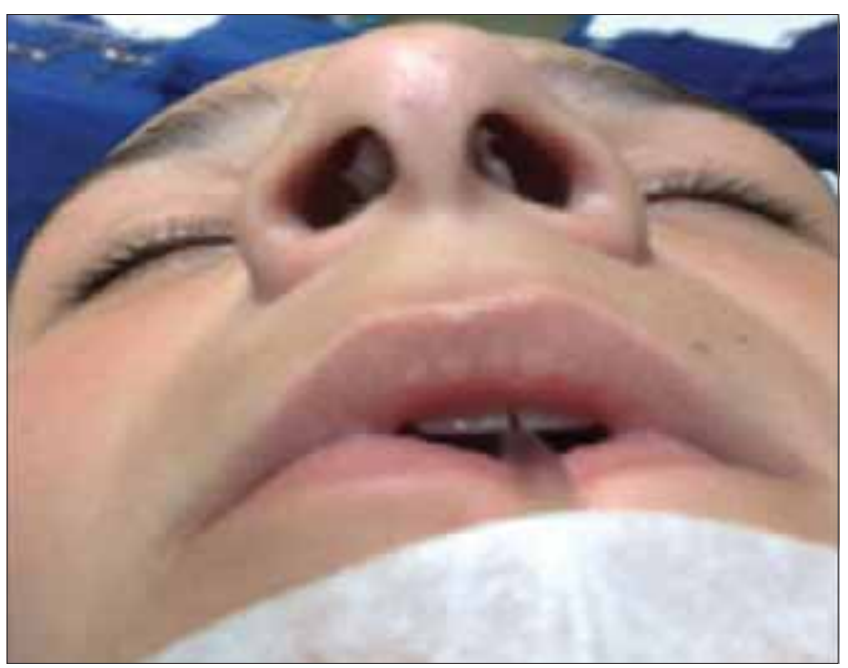

Figure 17. Pre operative view basis.

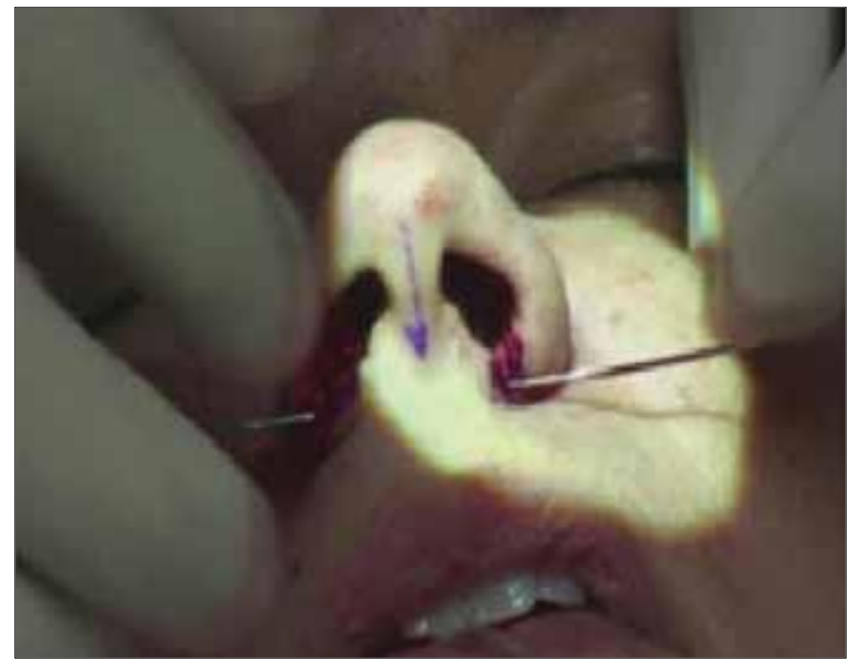

Figure 14. Step 4.

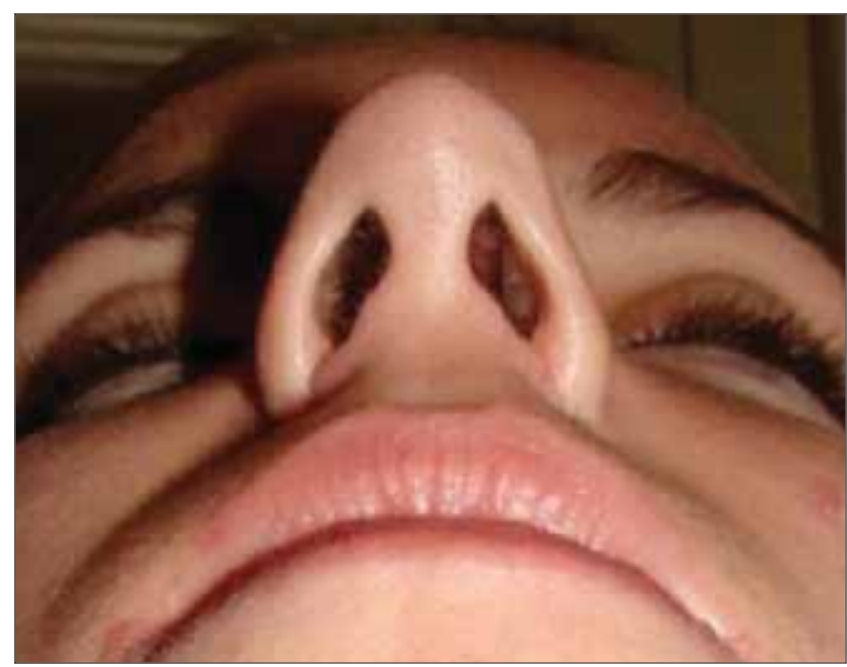

Figure 16. Post-operative view of the base.

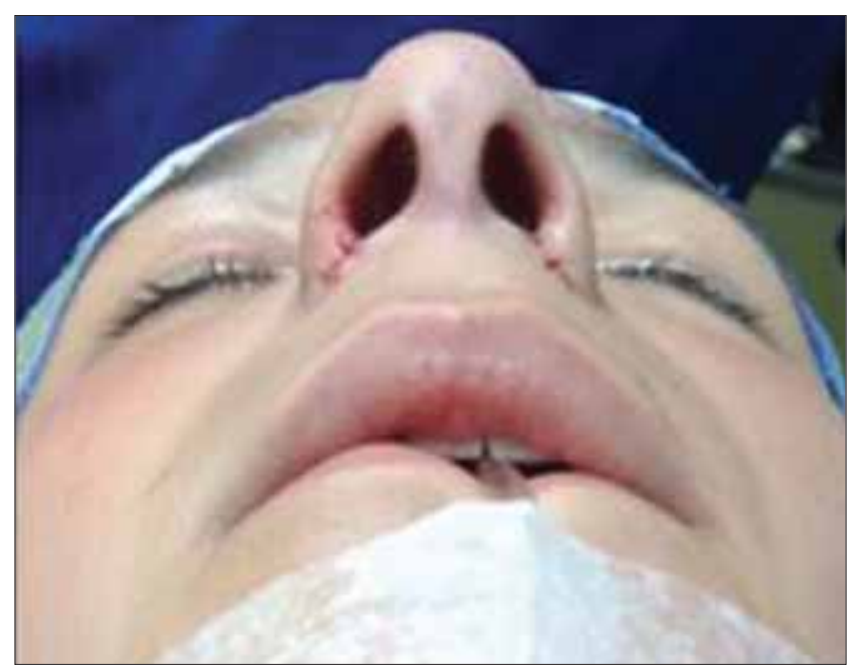

Figure 18. Post-operative view of the base. 


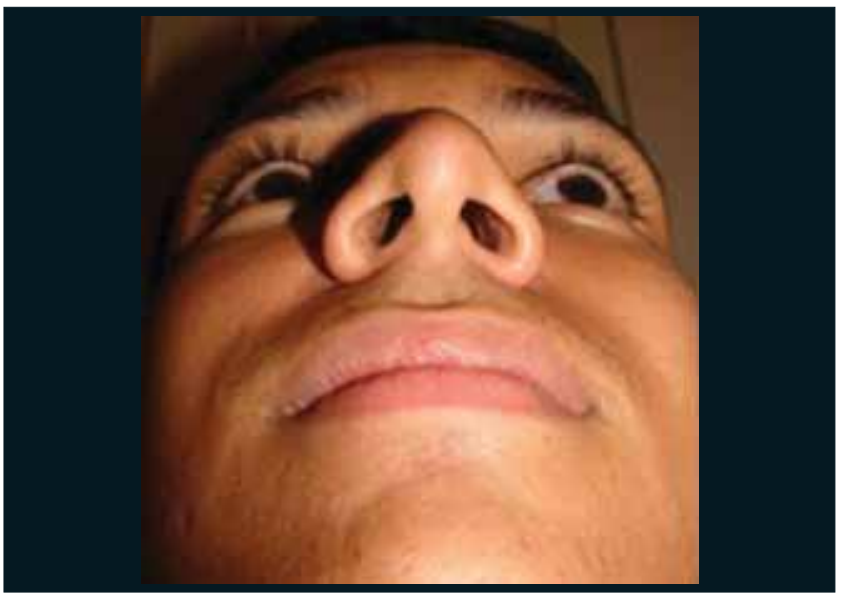

Figure 19. Pre operative view basis.

Case III - A male patient, 20 years, thick skin, preand postoperative 12 months

\section{DISCUSSION}

Holding sutures with smaller resections of skin and cartilage in rhinoplasty is a global trend. The assessment of nasal aesthetic points including the nasal base is part of the success of rhinoplasty (1-9). The smaller the resection of skin and non-intervention in the vestibule, the less chance of complications (7). The detachment of the skin and musculature of the region of the premaxilla can be accomplished (3). The authors did not perform this detachment in this study.

The end result of the suture is mainly influenced by such factors as the presence of very broad nasal base, the intrinsic strength of the lower lateral cartilage, the degree of tightness of the point, the tensile strength of the wire and the limitation imposed by the soft tissues (ligaments, tissue subcutaneous and skin) (14).

Skin thickness is a determining factor in the effectiveness of the suture. In patients with thin skin and subcutaneous tissue scarce, as in the Caucasian nose, the results are more expressive. In patients with very thick skin and excess subcutaneous tissue, the suture can become less effective and should be performed to decrease the inter-alar distance by other means $(2,3,6)$.

According to the authors, the technique of cerclage of the nasal base has details which must be observed:

1. Take the projection of the columella base;

2. Do not apply for correction of asymmetric nostrils;

3. Must be undertaken on a bilateral basis, avoiding holes narinários asymmetrical;

4. Approach is made by subcutaneous cerclage;

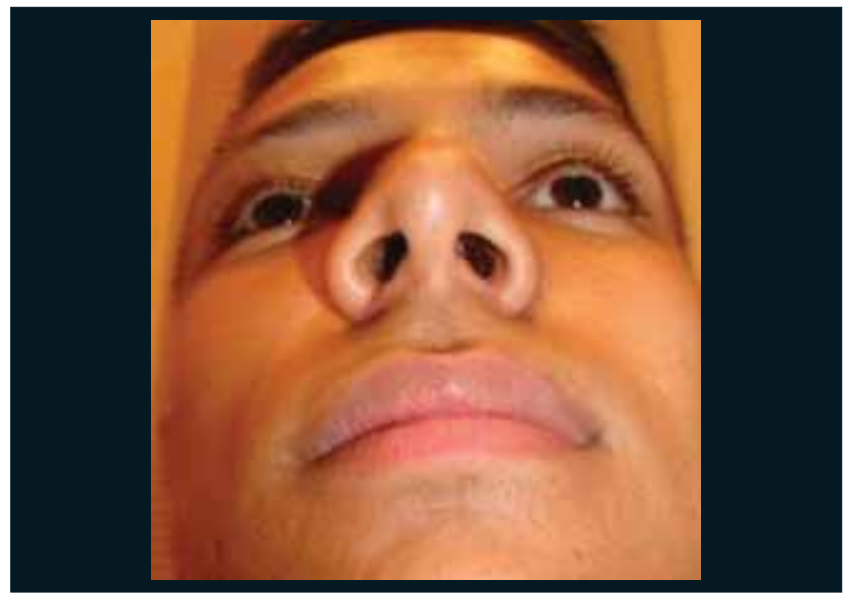

Figure 20. Post-operative view of the base.

5. The result is not suitable in very large nasal base.

The suture can be performed with absorbable sutures long-term or wired nonabsorbable (7.8), considering the tensile strength and degree of reabsorption of each wire. In all cases we used nonabsorbable sutures (mononylon ${ }^{\circledR} 4.0$ colorless) with no cases of extrusion or other complications described in literature (abscess, wire extrusion, asymmetry of the nostril.) Resection of the vestibule and the skin edges are fundamental narinário when combined with cerclage, because as mentioned by some authors, only the cerclage to the narrowing of the nasal base in the long term results are not very significant (2). On the nose with very wide base, this technique can leave the nostrils very round with undesirable cosmetic result in these cases other techniques are more suitable.

\section{CONCLUSION}

The suture cerclage in combination with resection of vestibular skin and the edge narinário (technique modified Weir) is an effective method to decrease nasal base (alar flare). This technique has been described in the literature with emphasis on the nose and mestizo african descent. This study also showed the wide applicability in the Caucasian nose.

It is easy to perform a suture, predictable, controlled and extremely useful in the armamentarium of the surgeon for surgery of the nasal base.

\section{BibliOgRAPHICAL REFERENCES}

1. Daniel RK. The Nasal Base: Aesthetic Plastic SurgeryRhinoplasty. Boston, Mass: Little Brown \& Co Inc; 1993: 307-312. 
2. Foda H. Nasal Base Narrowing: The Combined Alar Base Excision Technique. Arch Facial Plast Surg. 2007, 9:30-34.

3. Gruber R, Freeman M, Hsu C. Nasal Base Reduction: A Treatment Algorithm Including Alar Release with Medialization. Plastic and Reconstructive Surgery. 2009, 2:716-725.

4. Oropeza F, Marín J, Chávez M. Manejo de la Base Nasal mediante Resección de Husos de Piel de la Columnella. Acta Otorrinolaringol Esp. 2006, 57:405-411.

5. Tardy ME, Brown RJ. Surgical Anatomy of the Nose. New York: Raven Press, 1990.

6. Kridel, R. A Simplified Approach to Alar Base Reduction: A review of 124 Patients over 20 years. Archives of Facial Plastic Surgery. 2005, 7(2):81-93.

7. Bennett G, Lessow A, Song P, Constantinides M. The Longterm Effects of Alar Base Reduction. Arch Facial Plast Surg. 2005, 7:94-97.

8. Rohrich RJ, Adams WP. The Boxy Nasal Tip: Classification and Management Based on Alar Cartilage Suturing Techniques. Plast Reconst Surg. 2001, 1849:107.

9. Rees TD. The Lip-Tip-Columella Complex and the Alar Base: Aesthetic Plastic Surgery. Philadelphia, Pa:WBSaunders Co; 1980, 1:269-283.

10. Wier RF. On restoring sunken noses without scarring the face. N Y Med J. 1892, 56:449-454.

11. Converse JM. Corrective rhinoplasty. In: Converse JM. Reconstructive Plastic Surgery. Philadelphia, Pa: WB Saunders Co; 1977, 2:1091-1093.

12. Maniglia AJ, Maniglia JJ, Maniglia JV. Rinoplastia EstéticaFuncional-Reconstrutora. $1^{\underline{a}}$ ed. Revinter 2002: 129-150.

13. Sheen JH, Sheen AP. Adjunctive Techniques: Aesthetic Rhinoplasty. St Louis, Mo: CV Mosby Co; 1987, 1:252-272.

14. Perkins S, Patel A. Endonasal Suture Techniques in Tip Rhinoplasty. Facial Plast Surg Clin North Am. 2009, 17(1):4154. 